\title{
New Neolithic cult centres and domestic settlements in the light of Urfa Region Surveys
}

\author{
Bahattin Çelik \\ Department of Archaeology, University of Ardahan, Ardahan, TR \\ bahattincelik@ardahan.edu.tr
}

\begin{abstract}
The present study concerns Neolithic period cult centres and settlements discovered recently during surface surveys in the central district of Urfa (Sanlurfa) region in south-eastern Turkey. The presence of T-shaped pillars was ascertained at Ayanlar Höyük and Kurt Tepesi cult sites. Other settlements are domestic settlements arranged around cult centre settlements. Some sites belong to Pre Pottery Neolithic, and the others to Pottery Neolithic. They are believed to be coeval with Göbekli Tepe and Nevali Cori cult sites.
\end{abstract}

IZVLEČEK - V študiji predstavljamo neolitska naselja in kultna središča, ki so bila nedavno odkrita med terenskimi pregledi $v$ osrednjem delu regije Urfa (Sanluurfa) v jugovzhodni Turčiji. Tako imenovani T stebri so bili dokumentirani v kultnih središčih Ayanlar Höyük and Kurt Tepesi. Okoli središč so bila odkrita običajna naselja, nekatera datirana v pred-keramični, druga v keramični neolitik. Sočasna so s kultnima središčema Göbekli Tepe in Nevali Çori.

KEY WORDS - Sanluurfa; Pottery and Pre-Pottery Neolithic (PPN); cult buildings; round buildings; domestic buildings

\section{Introduction}

The important role played by the South-eastern Anatolia region in the emergence of precursor settlements and cult centres during the Pre-Pottery Neolithic Period is better comprehended every day as new settlements are discovered. The discovery of settlements such as Nevali Cori (Hauptmann 1993.3769; 1999.66-86), Göbekli Tepe (Beile-Bohn et al. 1998.5-78; Schmidt 2001.45-54; 2002.8-13; 2007. 115-129), Sanliurfa-Yeni Mahalle (Celik 2000a.46; 2007.165-178; 2011a.139-164), Karahan Tepe (Celik 2000b.6-8; 2011b.241-253), Sefer Tepe (Celik 2006a.23-25; Güler et al. 2012.161-162, 168169), Hamzan Tepe (Celik 2004.3-5; 2006b.222224; 2010.257-268), Taşlı Tepe (Celik et al. 2011. 225-236; Güler et al. 2013.292-293), İnanl Tepesi (Güler et al. 2013.291-304), Kocanizam Tepesi (Güler et al. 2012.160, 167-168), Başaran Höyük (Güler et al. 2012.158-159, 165-166) and Herzo Tepe (Güler et al. 2012.159-160, 166-167) as a result of surveys conducted in recent years particularly in the Urfa region constitutes the best evidence for this fact (Map 1).
It is believed that, at such settlements recently discovered in the Urfa region, especially the Neolithic societies adopted a predominantly hunter/gatherer way of life. Today, excavations of this period are being carried out only at Göbekli Tepe, Nevali Çori and Şanlıurfa-Yeni Mahalle. Other settlements in the region with identical characteristics, such as Hamzan Tepe, Karahan Tepe, Sefer Tepe and Taşlı Tepe, have not been excavated yet. The common feature of such settlements is the presence of T-shaped pillars, like at Göbekli Tepe and Nevali Cori. Finds that are either similar or the successors to such pillars were also unearthed in the Adiyaman (Hauptmann 2000.5-9; 2012.13-22) and Gaziantep (Bulgan, Celik 2011.85-90; Celik 2005.28-29) regions located on the western banks of the Euphrates, proving that the phenomenon was even more widespread than previously thought.

Nineteen Neolithic sites were examined as a result of the studies conducted in the Urfa region, at Kurt Tepesi, Guhera Abid Mevkii, Selamet Kuzey Mevkii, Se- 
lamet Kuzey Höyüğü, Çamçak Tepesi, Terzi Village Batı Mevkii, Sıluba Tepesi, Aşağ1 Yazıcı Güney Mevkii, Mınzilit Feriş, Mınzilit Hıleyil, Mınzilit İsa, Karakuş Kuzeybatı Mevkii, Çillo Mevkii 1, Çillo Mevkii 2, Domuzcurnu Tepesi, Nebi Tarlası, Ömer Altundağ Tarlası, Hasan Sirtı and Ayanlar Höyük, respectively. Among these sites, T-shaped pillars were discovered at Kurt Tepesi. At Ayanlar Höyük, on the other hand, a pedestal piece of what are thought to be T-shaped pillars and a lion head used for cult purposes have been unearthed. Based on these finds, Ayanlar Höyük

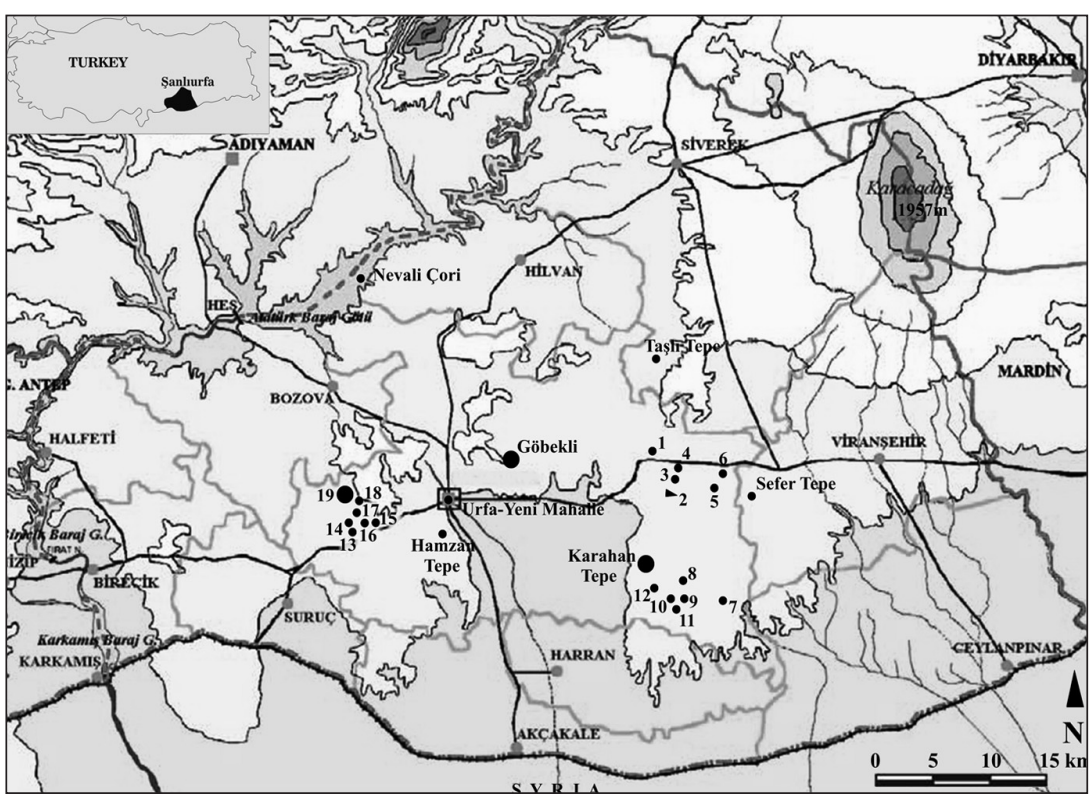

Map 1. Map illustrating the Neolithic sites in Urfa province. is also thought to be a cult centre. Flintstone tools and ceramics with characteristics of the Neolithic have been found at other sites. Selamet Guhera Abid Mevkii is one of the interesting sites discovered, and is thought to be a large snare area designed for catching animals during this period.

\section{Kurt Tepesi}

The mound, known locally as Kuça Gur, is located $45 \mathrm{~km}$ east of Sanliurfa province and $3 \mathrm{~km}$ south of Sumaklı village (Map 1.1) at $730 \mathrm{~m}$ above sea level (a.s.l.). It is located on a hill dominating Çoban Deresi Boğazı (Çoban Creek Pass), which functions as a passageway between the Harran plain and the $\mathrm{Vi}$ ranşehir region (Fig. 1). It is a small mound established on a ridge formed by high calcareous plateaus, which is very poor in terms of soil. Several sacked tumuli from the Roman period were located around this mound, covering an area of approx. 1ha. The mound is distorted due to illegal excavations; moreover, a high voltage transmission line pole is located at the north end Small cavern groups and pools carved into the bedrock were found in the calcareous rocks surrounding the mound (Fig. 2). Negative traces of a T-shaped pillar are apparent at an illegal excavation pit in this area, which is thought to date to the Pre-Pottery Neolithic (Fig. 3). During the investigation conducted in the region, pillars which had been removed from their original site were discovered at Kösecik village, approx. $6 \mathrm{~km}$ southeast of Kurt Tepesi (Fig. 4) 1 . Only flint and very scarce obsidian finds were unearthed at the settlement; the finds include scrapers and drills and flint arrowhead fragments (Pl. 1.a-h). Moreover, stone beads, and pestle parts made from basalt stone were also discovered.

\section{Guhera Abid Mevkii}

This site is located $48 \mathrm{~km}$ east of Şanliurfa and $500 \mathrm{~m}$ northwest of Selamet village (Map 1.2) at 700m a.s.l. Two large trap sites for hunting wild game were discovered here (Bar-Oz on-line), laid out on the eastern slope of a hill and extending to form a triangle starting from the hill towards the valley plain (Fig. 5). The trap site has walls made from large flagstones, which are irregular and form a triangle with angles of approximately $50^{\circ}$. There are no wall remnants at the short edge of this triangle extending down from the hill. A wall remnant in the form of a circle of approx. $5 \mathrm{~m}$ in diameter is present at the end of both converging long edges. Flint blades and flakes were discovered during the research in this area. Guhera Abid locality, where the traps are located, is approx. $3.5 \mathrm{~km}$ southeast of the Kurt Tepesi settlement.

\section{Selamet Kuzey Mevkii}

This site is located $48 \mathrm{~km}$ east of Şanliurfa and $1 \mathrm{~m}$ north of Selamet village (Map 1.3). The settlement is on south-facing slope (Fig. 6) at $645 \mathrm{~m}$ a.s.l., and covers approx. 0.5ha. Four tumuli were destroyed due to illegal excavations. Flint blades, flakes, and

1 The pillars were brought from Kuça Gura settlement by Hüseyin and Sinan Eyyüboğlu, who live in Kösecik village. (Private interview with İbrahim Eyyüboğlu, 20.10.2013.) The pillars are now in the Şanllurfa Museum. 
Byblos and Nemrik type arrowheads were discovered during research in this area (Pl. 1.i-1).

\section{Selamet Kuzey Höyü̆ğ̈i}

The mound, which is very small, extends over only approximately $0.2 \mathrm{ha}$. It is located $1.5 \mathrm{~km}$ north of Selamet village on a hill (Map 1.4) at $672 \mathrm{~m}$ a.s.l. A remnant of a circular plan structure unearthed as a result of illegal excavations has been found here present (Fig. 7). Also, flint blades and flakes, as well as Babylos points and scrapers as fragments were discovered as a result of research. A Paleolithic open-air site was found $100 \mathrm{~m}$ west of the settlement, where research yielded a Levallois core and points.

\section{Camçak Tepesi}

This site is located $1 \mathrm{~km}$ south of Kuşharabesi village and $61 \mathrm{~km}$ east of Şanliurfa (Map 1.5), at $676 \mathrm{~m}$ a.s.l. The site covers approx. 0.8ha. The settlement is situated on a calcareous hill (Fig. 8). Circular architectural remains were unearthed by illegal excavations (Fig. 9). Blades, flakes, waste products and some point fragments were discovered by researchers. This site is approx. $7 \mathrm{~km}$ northwest of the Sefer Tepe settlement.

\section{Terzi Batı Mevkii}

This site, approx.1ha in area, is on a south-facing slope, approx. $1 \mathrm{~km}$ west of Terzi village and $63 \mathrm{~km}$ east of Şanliurfa at $645 \mathrm{~m}$ a.s.l. (Map 1.6). Research revealed that the settlement was inhabited during the Early Byzantine period, and the Chalcolithic and Neolithic period. Neolithic flint blades, flakes and point fragment were discovered at the site. This settlement site is approx. 6km northwest of Sefer Tepe.

\section{Suluba Tepesi}

This site is situated approx. $1.4 \mathrm{~km}$ northeast of Y1ldizlı village and $90 \mathrm{~km}$ southeast of Şanliurfa, at $522 \mathrm{~m}$ a.s.l. (Map 1.7). Lying between two hills, the site is covering an area of approx. 2ha. It has an earth embankment approximately $1 \mathrm{~m}$ high. During research at this site, a sacked tumulus from the Roman period was discovered on the western hill. The surface survey revealed flint flakes, blades and unipolar cores (Pl. 1.m-r).

\section{Aşăğ Yazıcı Güney Mevkii}

This site, $1.2 \mathrm{~km}$ southeast of Aşağı Yazıcı village and $82 \mathrm{~km}$ southeast of Şanliurfa (Map 1.8), is covering an area of approx. 0.6ha, and is located at $56 \mathrm{~m}$ a.s.l. The settlement is on a slightly inclined crater area between two calcareous hills (Fig. 10), surrounded by calcareous hills to the north, east and south, with only the section facing west being open. During the survey of this area, small ponds carved into the calcareous rocks located east of the settlement were found; also, flint blades and flakes, some points and point fragments (Pl. 1.s-x), straw temper ceramics from the Pottery Neolithic period and ceramic fragments from later periods were discovered.

\section{Minzalut Feriş}

This site is approx. 1.6km west of Altıntepe (Resmeldehab) village, and located $77 \mathrm{~km}$ southeast of Şanliurfa, situated at $612 \mathrm{~m}$ a.s.l. (Map 1.9). The settlement is on a slightly inclined crater area between two calcareous hills and surrounded by calcareous hills to the north, east and west, with only the section facing south being open. The site is approximately 0.1 ha in area. The earth embankment of the settlement varies in height between approx. $50 \mathrm{~cm}$ and $1 \mathrm{~m}$. No architectural remains were discovered here, but the survey yielded ceramics from the Neolithic, late Chalcolithic, early Bronze and late Byzantine periods. Flint blades and flakes, some scraper fragments, and a very small amount of obsidian were also found (Pl. 2.a-f).

\section{Monzilnt Holeyil}

This site is located approx. $1.3 \mathrm{~km}$ west of Altıntepe village, $77 \mathrm{~km}$ southeast of Sanliurfa and at an altitude of $596 \mathrm{~m}$ a.s.l. (Map 1.10). The site, covering approx. $0.5 \mathrm{ha}$ in area, is on a slightly inclined crater area between two calcareous hills (Fig. 11) and surrounded by calcareous hills to the north, east and west, with only the section facing south being open. No architectural remains were discovered at the settlement, as the area is currently in use as a field. The survey conducted here yielded ceramics from the Neolithic, late Chalcolithic, early Bronze, early Byzantine and Islamic periods. Moreover, flint blades, flakes, retouched blades, point fragments and scrapers were found (Pl. 2.g-j).

\section{Monzulut Isa}

This site is situated approx. $1 \mathrm{~km}$ west of Altintepe village and $77 \mathrm{~km}$ southeast of Şanlıurfa, at $611 \mathrm{~m}$ a.s.l. (Map 1.11). The settlement is on a slightly inclined crater area between two calcareous hills (Fig. 12), surrounded by calcareous hills to the north, east and west, with the section facing south being open. The site covers an area of approx. 0.2ha. The earth embankment of the settlement varies in height between $1-2 \mathrm{~m}$. No architectural remains were discovered here, as the settlement area is currently in use as a field. As a result of the survey of this area, ce- 


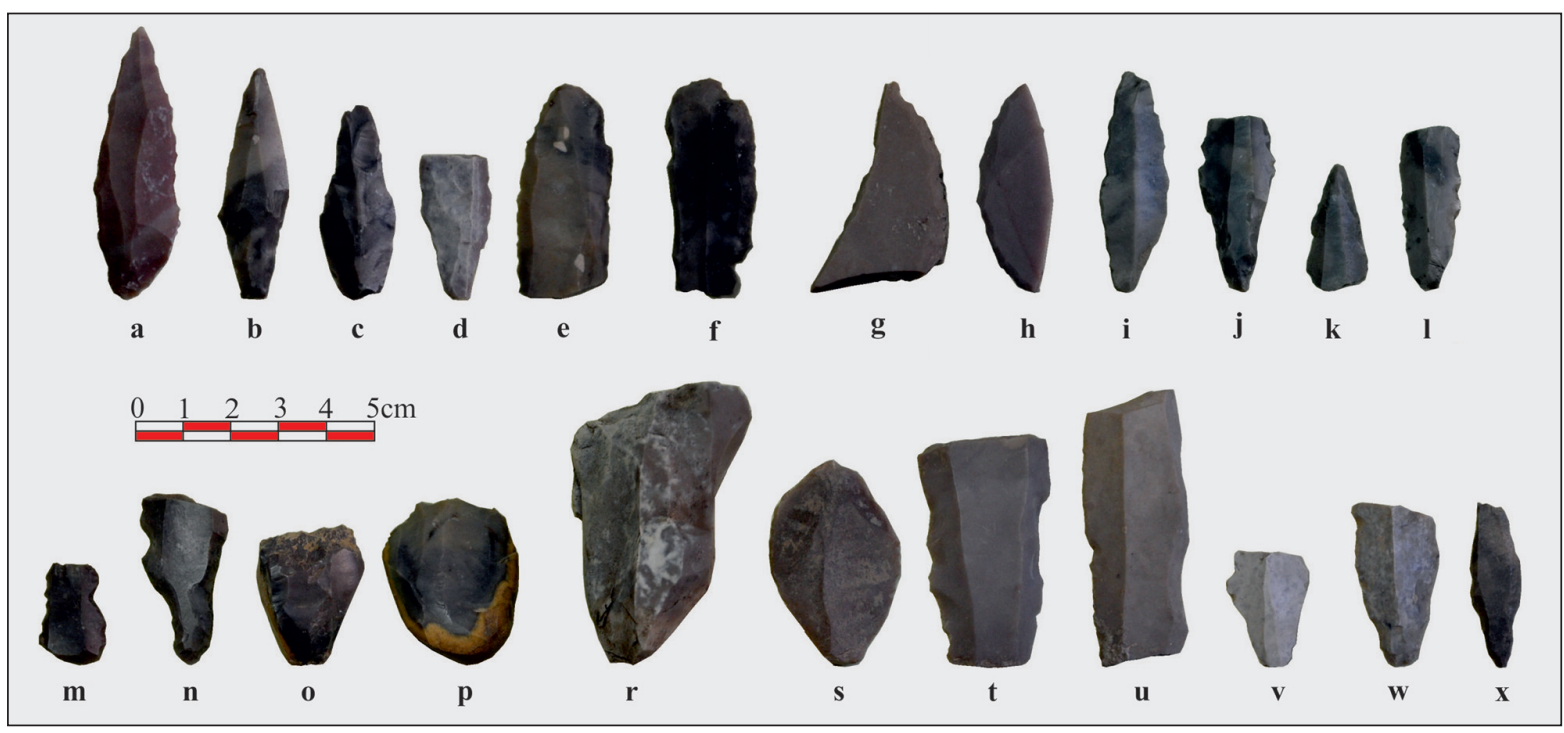

Pl. 1. Finds from Kurt Tepesi (a-h), Selamet Kuzey Mevkii (i-l), Sıluba Tepesi (m-r) and Aşağı Yazıcı Güney Mevkii $(s-x)$.

ramics from the Neolithic, Chalcolithic and early Byzantium periods were discovered. Moreover, flint blades and flakes made, some point fragments, scrapers, drills and obsidian were discovered as small finds (Pl. 2.k-r).

\section{Karakuş Batı Mevkii}

This site is located approx. $3 \mathrm{~km}$ west of Karakuş village and $70 \mathrm{~km}$ southeast of Şanliurfa, at $539 \mathrm{~m}$ a.s.1. (Map 1.12). Lying on the slope of a stream bed facing south, the settlement covers approx. 1.1ha (Fig. 13). A dry stream bed flowing east to west is located north of the settlement. No architectural remains were discovered here, as the settlement area is currently in use as a field. As a result of the survey in this area, ceramics from early Byzantine periods as well as flint blades, flakes, end scraper fragments were discovered (Pl. 2.s-x).

\section{Cillo Mevkii 1}

This site is a hillside settlement located approx. $1 \mathrm{~km}$ north of Ciralı village and $24 \mathrm{~km}$ west of Sanlıurfa, at $668 \mathrm{~m}$ a.s.l. (Map 1.13). The settlement is covering an area of approx. 0.5ha (Fig. 14). No architectural remains were discovered, as the area is currently in use as a field. The survey yielded ceramics from the Early and Mid-Byzantium and Neolithic periods (Pl. 3.g-k) and a flint bifacial tool from the Middle Paleolithic as well as abundant amounts of blades and flakes, unipolar cores and scrapers (Pl. 3.a-f).

\section{Cillo Mevkii 2}

This is a hillside settlement located approx. $1.5 \mathrm{~km}$ north of Çıralı village and $24 \mathrm{~km}$ west of Şanlıurfa, at approx. 658m a.s.l. (Map 1.14). The settlement is covering an area of approx. 0.5ha (Fig. 15). No architectural remains were discovered, as the settlement area is currently in use as a field. As a result of the survey, ceramics from the Early Byzantine and Neolithic periods (Pl. 3.p-t) were discovered. Flint blades and flakes and scrapers and point fragments were also unearthed (Pl. 3.1-0).

\section{Domuzcurnu Tepesi}

This site is located $3.5 \mathrm{~km}$ southeast of Kizllburç village and $28 \mathrm{~km}$ west of Şanlıurfa, at $743 \mathrm{~m}$ a.s.l. (Map 1.15). The settlement is covering an area of approx. 0.5 ha (Fig. 16), lies on a low calcareous hill, and is surrounded by basalt deposits. It is a well-preserved site, with traces of some walls visible. As a result of the surveys, flint blades, flakes, unipolar core, core replacement fragments and hammer and some point fragments, scraper fragments, drills and blade with sheen were discovered dating back to the PrePottery Neolithic (Pl. 3.u-z). A very small amount of obsidian blade and flake parts were also found.

\section{Nebi Tarlasi}

This site is situated $2 \mathrm{~km}$ southwest of Kizllburç village and $28 \mathrm{~km}$ west of Şanlıurfa, at approx. $699 \mathrm{~m}$ a.s.l. (Map 1.16). The settlement is covering an area of approx. 0.8ha. No architectural remains were discovered, as the settlement area is currently in use as a field. The survey yielded straw temper ceramics from the Neolithic and flint blades and flakes and scrapers were also discovered (Pl. 4.a-d). Also the usual amount of obsidian blades and flakes was also discovered. 


\section{Ömer Altundă Tarlası}

This site is located $1 \mathrm{~km}$ south of Kuzlburç village and $28 \mathrm{~km}$ west of Sanliurfa, at $701 \mathrm{~m}$ a.s.l. (Map 1.17). The settlement is covering an area of approx. $0.1 \mathrm{ha}$, on the slope of a calcareous hill; basalt deposits are available to the east. The settlement has been destroyed by agricultural activity. As a result of surveys, ceramics from the Neolithic and early Byzantium periods, and flint blades and flakes and core replacement fragments were discovered ( $\mathrm{Pl}$. 4.e-h).

\section{Hasan Sirt}

This site is located $1 \mathrm{~km}$ north of Kuzllburç village and $28 \mathrm{~km}$ west of Şanliurfa (Map 1.18). The settlement is approx. 0.6ha in area at $752 \mathrm{~m}$ a.s.l. (Fig. 17). The settlement is on the western slope of a calcareous hill; basalt deposits are available to the east. The settlement was destroyed by agricultural activity. As a result of the surveys, straw temper ceramics from the Neolithic period and Early Byzantine ceramics were discovered. Flint blade and flake fragments and scraper fragments were also discovered (Pl. 4.i-l); a basalt stone upper grinding stone was also found.

\section{Ayanlar Höyük}

This site is located underneath and to the north of Ayanlar (Hut) village, $30 \mathrm{~km}$ west of Şanlıurfa, at $733 \mathrm{~m}$ a.s.l. (Map 1.19). It is covering an area of approx. 14ha (Fig. 18). The mound, which was destroyed by agricultural activity, is around $10 \mathrm{~m}$ high. The village settlement is located on the southern section of the mound, which comprises five hills. Basalt deposits are available $2 \mathrm{~km}$ to the east. The surveys revealed ceramics from the early and mid-Byzantine periods. Flint blades and flakes, unipolar and bipolar cores, core replacement fragments, scraper fragments, point fragments, hammer and rested blade fragments were discovered (Pls. 4.m-v, 5.a-b). Very small amounts of obsidian blade and flake parts were also revealed. Lower and upper basalt grindstones, stone bowl fragments, stone plate and pestles were among the other finds (Pl. 5.c-g). Limestone cubes and pedestal fragments from hollow stone, which we know were made for pillars (Fig. 19) were also discovered during surveys in the village. Also, small pole groups carved into the bedrock (Fig. 20), which are familiar from Göbekli Tepe (Beile-Bohn 1998. Abb. 20), Karahan Tepe (Celik 2011b.Fig. 5) and Hamzan Tepe (Celik 2004.Figs. 2-3; 2006b.Figs. 3-

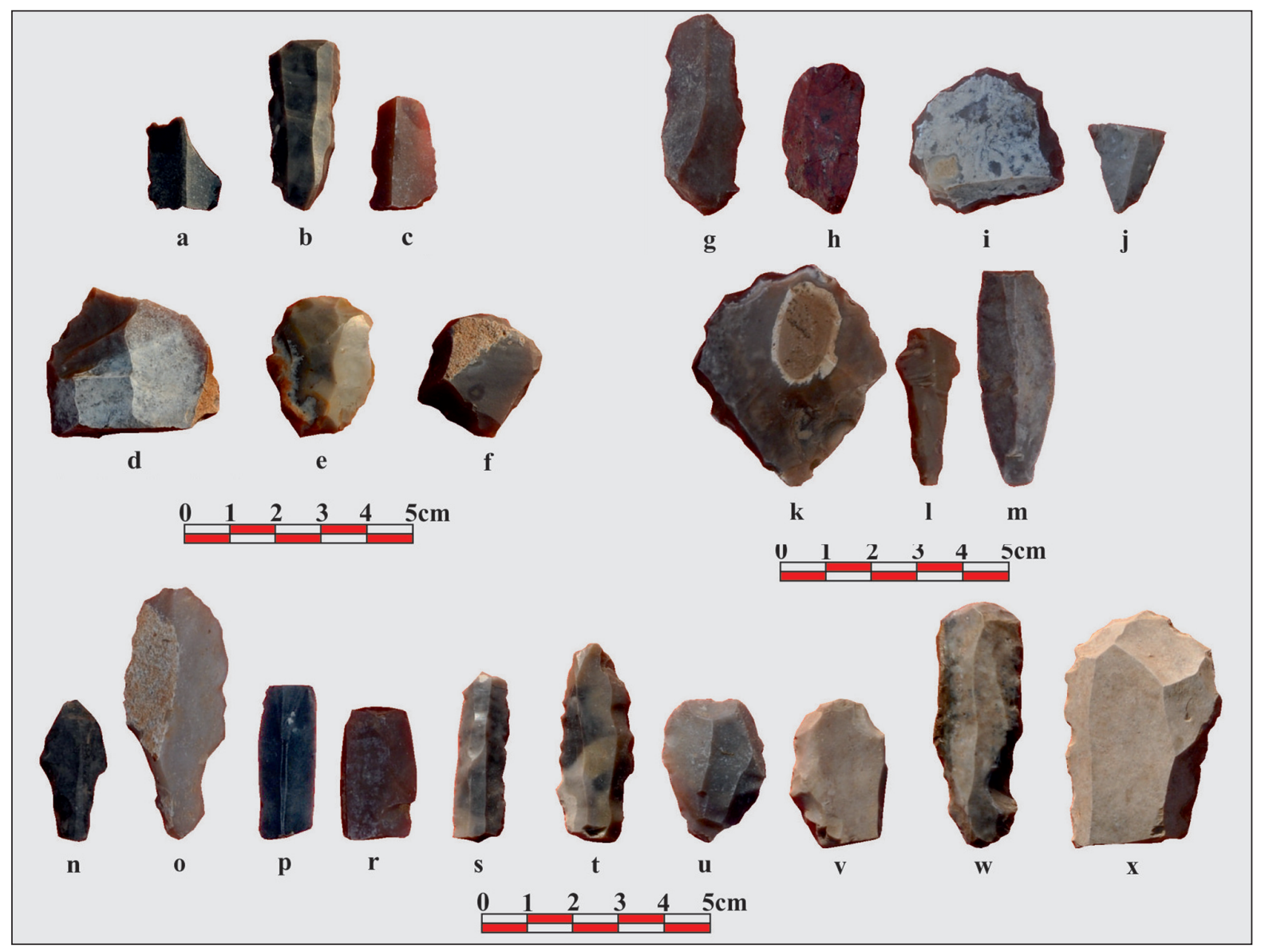

Pl. 2. Monzılıt Feriş (a-f), Monzılıt Hıleyil (g-j), Monzılıt İsa (k-r) and Karakuş Batı Mevkii (s-x). 


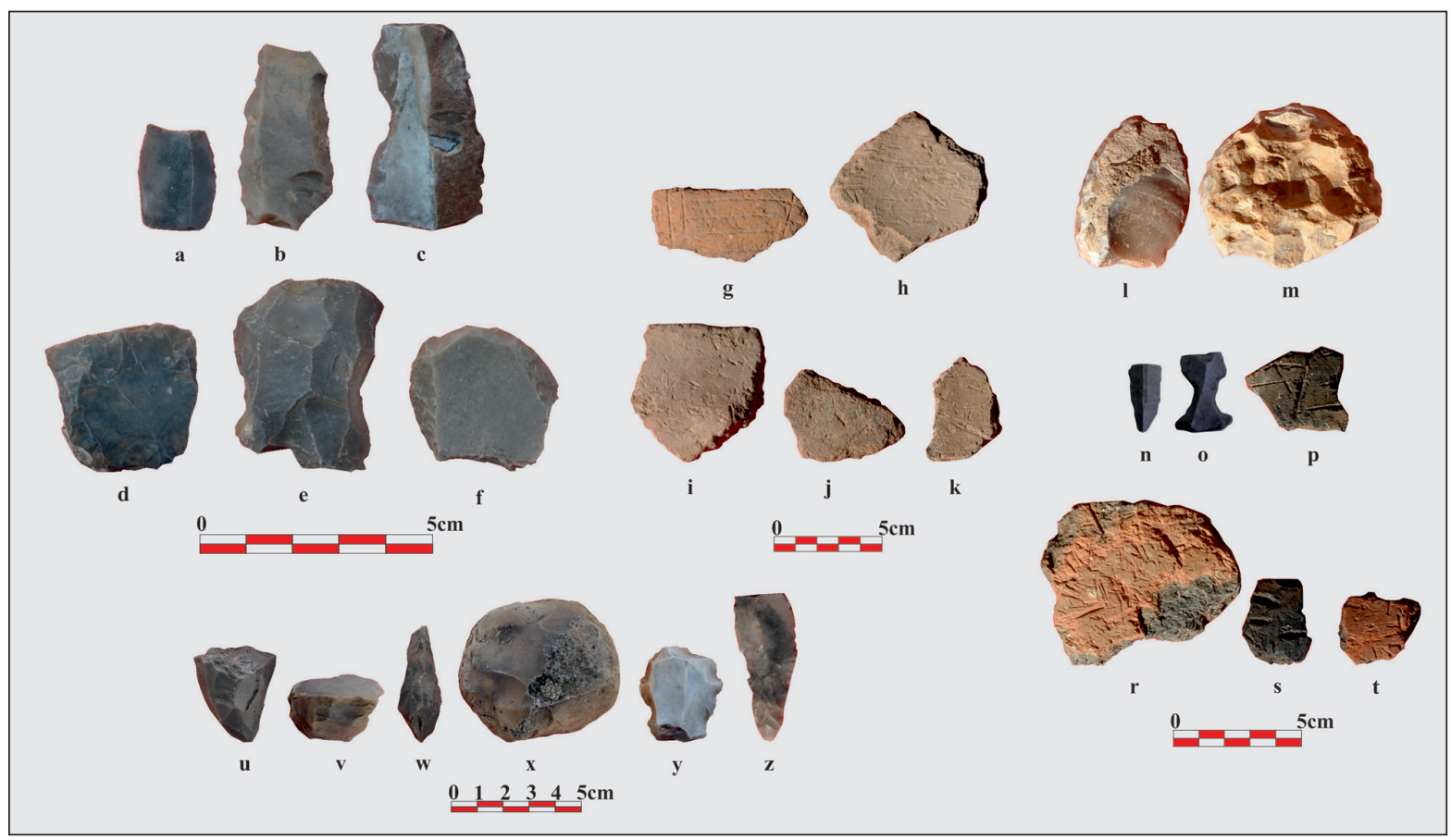

Pl. 3. Flintstone finds from Cillo Mevkii 1 (a-f), ceramic finds from Cillo Mevkii 1 (g-k), flintstone finds from Çillo Mevkii 2 (l-o), ceramic finds from Çillo Mevkii $2(p-t)$ and Domuzcurnu Tepesi $(u-z)$.

4; 2010.Figs. 6-8) were also discovered around the settlement.

\section{Assessment and conclusion}

Circular building architecture was unearthed at Selamet Kuzey Höyüğü and Çamçak Tepe amongst the recently discovered sites. The remains of circular buildings were observed at Herzo Tepe (Güler et al. 2012.Fig. 4), İnanlı Tepe (Güler et al. 2013. Fig. 8), Hamzan Tepe (Celik 2010.Figs. 3-4) and ŞanliurfaYeni Mahalle (Celik 2000a.Fig. 3; 2007.162, Fig. 16; 2011a.142, Figs.14-16) during studies conducted in the region in previous years. Both T-shaped pillars and remains of circular buildings were encountered at Hamzan Tepe (Celik 2004.Fig. 4; 2006 b. Fig. 5; 2010.Fig. 2.4). Likewise, a body piece of a T-shaped pillar as well as the remains of circular architectural buildings were also discovered at Yeni Mahalle (Celik 2014.20, Fig. 21). The number of examples of this architectural tradition, which also resembles the circular cult buildings from Layers II and III of Göbekli Tepe, is gradually rising every day as a result of surface surveys (Schmidt 2010. Fig. 2). Examples of such buildings should date to the early stages of the Pre-Pottery Neolithic period. Similar buildings were also encountered at settlements such as Çayönü (Erim-Özdoğan 2011.191193, Fig. 6.9), Hallan Çemi (Rosenberg 2011.61-63,
Figs. 2-6), Gusir Höyük (Karul 2011.2-4, Figs. 4-5. 11), Hasankeyf Höyük (Miyake 2013.40, 43, 46-47) and Körtik Tepe (Özkaya, Coşkun 2011.90-93, Figs. 2-5).

The presence of T-shaped pillars is a feature common to the Göbekli Tepe, Nevali Çori, Karahan Tepe, Sefer Tepe, Taşlı Tepe, Hamzan Tepe and Adiyaman Kilișik settlements. These pillars were also encountered at Kurt Tepesi. One of the pillars unearthed at Kurt Tepesi has necktie-shaped groove and chevron pattern relief (Fig. 21) that we recognise from Göbekli Tepe (Schmidt 2007.118, Fig. 11) and Nevali Çori (Hauptmann 1993.51-53, Abb. 16). The chevron pattern on the pillar at Kurt Tepesi is distinct from the pattern on the pillars at Nevali Cori, as this pattern has a single strip. However, this pattern is similar to the single-strip pattern on pillar 18 at the centre of building D in Göbekli Tepe (Schmidt 2010.Fig. 8). In particular, the T-shaped pillars unearthed at Kurt Tepesi have several characteristics in common with Layer II of Göbekli Tepe and the cult building at Nevali Cori. Due to such similarities, Kurt Tepesi should be dated to the late PPPA and early PPNB.

Located approx. $10-15 \mathrm{~km}$ southeast of Karahan Tepe, the Mınzilit İsa, Mınzilit Feriş, Mınzilit Hıleyil and Aşağ1 Yazıcı Güney Mevkii settlements present, due to their location, characteristics distinct from the 


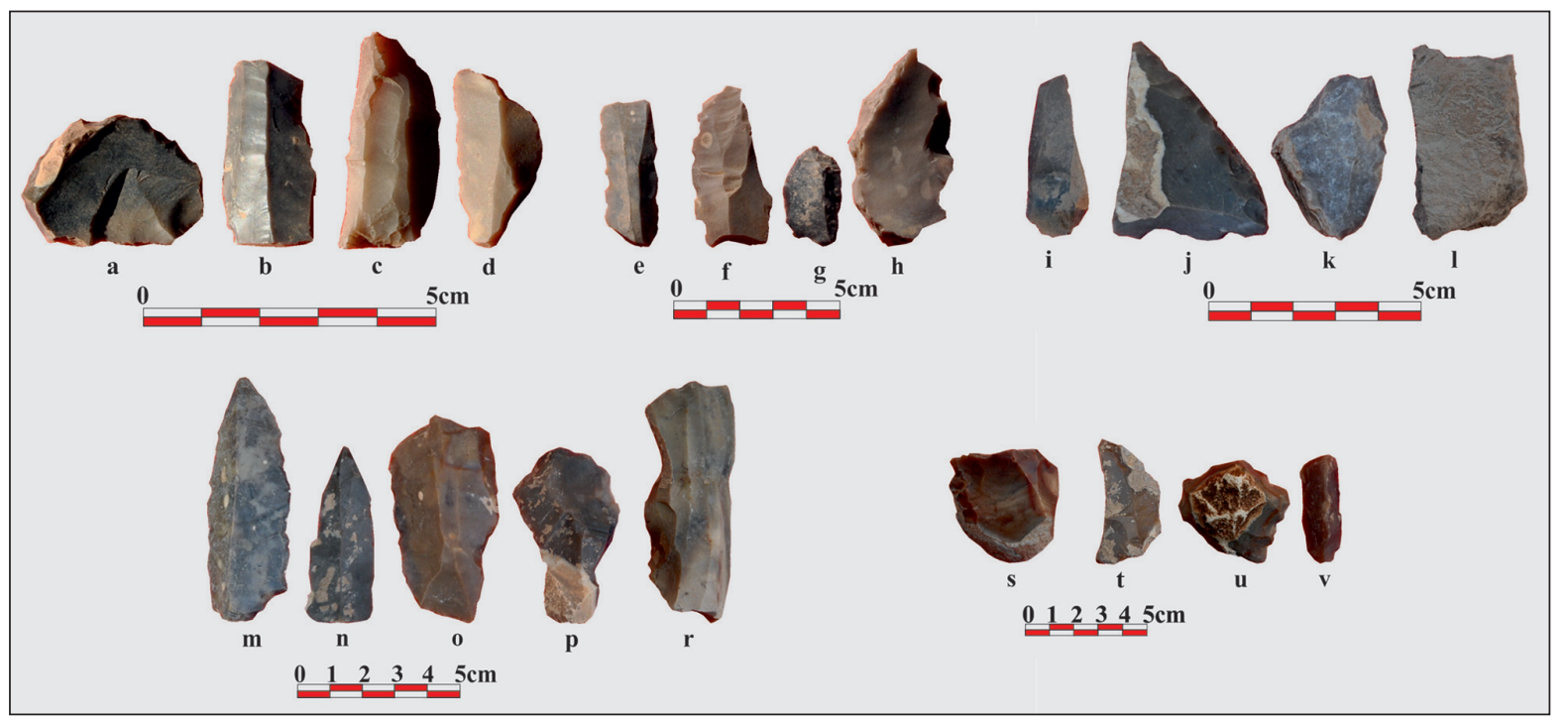

Pl. 4. Nebi Tarlası (a-d), Ömer Altundăg Tarlası (e-h), Hasan Sırtı (i-l), Ayanlar Höyük (m-v).

Neolithic settlements. The common feature of these settlements is that they are generally found on the southern slope of a rocky plateau and that they were inhabited in all periods. No architectural elements were encountered, as agricultural activities are being conducted on the land where the settlements are located. The fact that such small-scale settlements are located in the vicinity of Karahan Tepe, and that such settlements contain no cult finds suggest they might have been domestic settlements affiliated with Karahan Tepe cult centre.

Studies are being conducted at an area located approx. $25 \mathrm{~km}$ west of Şanluurfa city centre in order to understand the discovery site of two artefacts from the Pre-Pottery Neolithic brought to Şanliurfa Museum in 2013 (Ercan, Çelik 2013.Figs. 1a-d, 3a-d). The studies conducted revealed that Ayanlar Höyük extends over an area of approx. 14ha. As a result of the research, the settlement was identified as a settlement inhabited during the Pre-Pottery Neolithic.
Furthermore, seven additional satellite settlements thought to be affiliated to this settlement were also discovered during the surface survey carried out south of the Ayanlar Höyük. Domuzcurnu Tepesi, Nebi Tarlası, Ömer Altundağ Tarlası, Hasan Sırtı, Çillo Mevkii 1 and Çillo Mevkii 2 settlements, located at distances varying from $2-7 \mathrm{~km}$ from Ayanlar Höyük. Finds from both the Pre-Pottery and Pottery Neolithic were unearthed at these settlements. These settlements are arranged in the form of a large settlement site at the centre with smaller domestic settlements arranged around it, as at Karahan Tepe and Kurt Tepesi.

Guhera Abid Mevkii was probably used for mass hunting and snaring of wild animals. The site is located approx. $3 \mathrm{~km}$ southeast of the Selamet Kuzey Mevkii, Selamet Kuzey Höyüğü and Kurt Tepesi settlements. This large snare area, the largest encountered in the region so far, lies in a pass that separates the Harran Plain and Viranşehir plain. This site

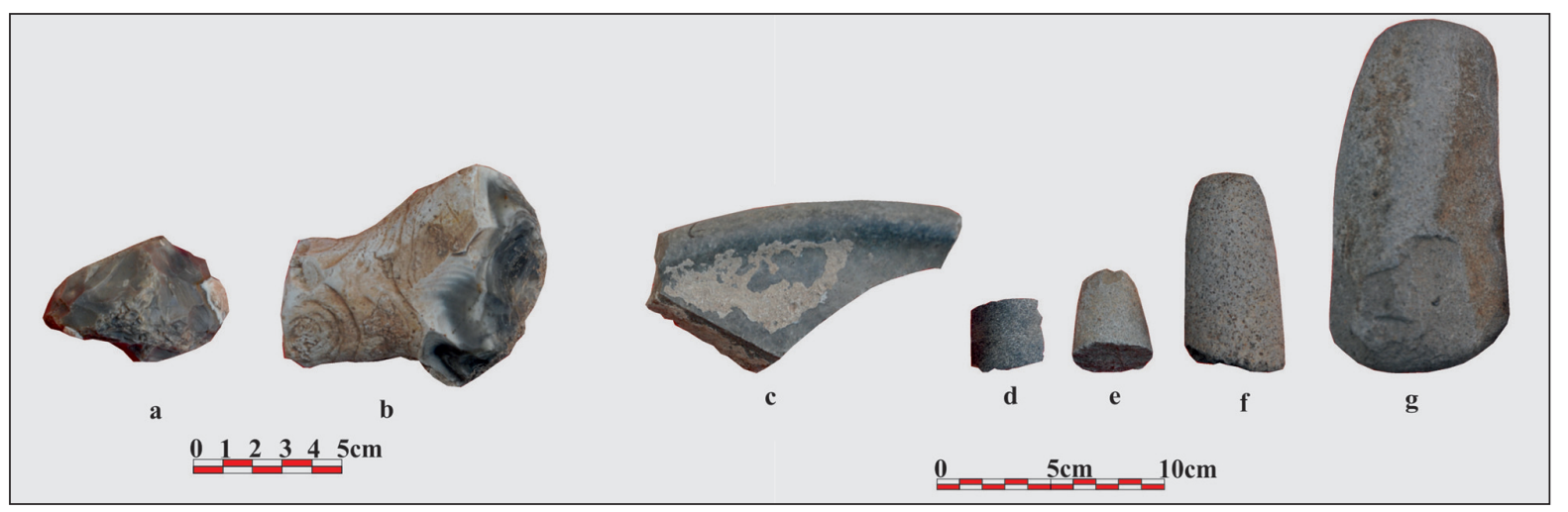

Pl. 5. Finds from Ayanlar Höyük (a-g). 
was most probably used for hunting antelope during the Neolithic period.

The Çamçak Tepesi and Terzi village Batı Mevkii Neolithic settlements are located approx. $7 \mathrm{~km}$ northwest of the Sefer Tepe site. These settlements were also probably domestic settlements of Sefer Tepe, like the Kocanizam, Başaran Höyük, Herzo Tepesi and İnanlı Tepesi settlements.

The Kurt Tepesi site has T-shaped pillars. An interesting fact is that this settlement is located at equal distances from both Karahan Tepe and Taşlı Tepe. Karahan Tepe, Taşlı Tepe and Kurt Tepesi are aligned in a north-south direction, with $15 \mathrm{~km}$ distance between the settlements. Another common aspect of these settlements, which are not yet excavated, is that probably all three were constructed only for cult purposes.
The studies conducted indicate that the number of settlements in the region from the Neolithic period is considerable. Moreover, the finds unearthed from several settlements not only represent the Pre-Pottery Neolithic but also the Pottery Neolithic period. The surface surveys revealed new cult buildings and domestic settlements that we believe were affiliated with such cult buildings. Research will continue in the future around the previously discovered cult buildings.

I would like to acknowledge the contributions of Türk Tarih Kurumu Başkanliğ Ahmet Essref Fakıbaba, former mayor of Sanlurfa Metropolitan Municipality, Mehmet Ekinci, Iffet Özgönül from Peten Tourism and Advertisement, and Ardahan University Scientific Research Project No 2014/1.

\section{References}

Bar-Oz et al. on-line http://www.antiquity.ac.uk/projgall/ bar-oz319.htm.

Beıle-Bohn M., Gerber C., Morsch M. and Schmidt K. 1998. Frühneolithische Forschungen in Obermesopotamien. Göbekli Tepe und Gürcütepe. Istanbuler Mitteilungen 48: 5-78.

Bulgan F., Çelik B. 2011. A New Statue From Gaziantep in Southeast Turkey. In H. Taşkıran, M. Kartal, K. Özçelik and G. Kartal (eds.), Işın Yalçınaya'ya Armağan Kitabı, Studies in Honor of Işın Yalçnkaya. Bilgin Kültür Sanat Yayinlar1. Ankara: 85-90.

Celik B. 2000a. An Early Neolithic Settlement in the Center of Şanlıurfa, Turkey. Neo-Lithics 2(3): 4-6.

2000b. A New Early-Neolithic Settlement: Karahan Tepe. Neo-Lithics 2(3): 6-8.

2004. A New Early-Neolithic Settlement: Hamzan Tepe. Neo-Lithics 2(04): 3-5.

2005. A New Statue of the Early Pre-Pottery Neolithic Period from Gaziantep. Southeastern Turkey. Neo- $i$ thics 1-05: 28-29.

2006a. A New Pre-Pottery Neolithic Site in Southeastern Turkey: Sefer Tepe. Neo-Lithics 1(06): 23-25. 2006b. A New Lower Paleolithic Open Air Station and Early Neolithic Settlement. In A. Erkanal-Öktü, E. Özgen, S. Günel, A. T. Ökse, H. Hüryılmaz, H. Tekin, N. Ç1nardal1-Karaaslan, B. Uysal, F. A. Karaduman, A. Engin, R. Spiess, A. Aykurt, R. Tuncel, U. Deniz and A. Rennie (eds.), Hayat Erkanal'a Armağan, Kültürlerin Yanstmasi, Studies in Honor of Hayat Erkanal, Cultural Reflections. Homer Yayınlar1. Istanbul: 222-224.

2007. Şanlıurfa Yeni Mahalle - Balıklıgöl Höyüğü. In M. Özdoğan, N. Başgelen (eds.), Anadolu'da Uygarlğn Doğusu ve Avrupa'ya Yaynlmi, Türkiye'de Neolitik Dönem, Yeni Kazllar, Yeni Bulgular. Arkeoloji ve Sanat Yayınları. Istanbul: 165-178.

2010. Hamzan Tepe in the Light of New Finds. Documenta Praehistorica 37: 257-268.

2011a. Şanlıurfa-Yeni Mahalle. In M. Özdoğan, N. Başgelen and P. Kuniholm (eds.), The Neolithic in Turkey, New Excavation and New Research, The Euphrates Basin. Archaeology and Art Publications. Istanbul: 139-164.

2011b. Karahan Tepe: A New Cultural Centre in Urfa Area in Turkey. Documenta Praehistorica 38: 241-253.

2014. Differences and Similarities Between the Settlements in Şanllurfa Region where "T" shaped Pillars are 
Discovered. In Ş. Dönmez (ed.), Turkish Academy of Sciences Journal of Archaeology. Türkiye Bilimler Akademisi Arkeoloji Dergisi 17: 9-24.

Çelik B., Güler M. and Güler G. 2011. A New Pre-Pottery Neolithic Settlement in Southeastern Turkey: Taşlı Tepe. Anatolia 37: 225-236.

Ercan M. and Çelik B. 2013. A Group of Artifacts from Neolithic Period in Şanlıurfa Museum. Anatolia 39: 13-54.

Erim-Özdoğan A. 2011. Çayönü. In M. Özdoğan, N. Başgelen and P. Kuniholm (eds.), The Neolithic in Turkey, New Excavation and New Research, The Tigris Basin. Archaeology and Art Publications. Istanbul: 185-269.

Güler M., Çelik B. and Güler M. 2012. New Pre-Pottery Neolithic Settlements from Viranşehir District. Anatolia 38: 157-191.

2013. New Pre-Pottery Neolithic sites and cult centres in the Urfa Region. Documeta Praehistorica 40: 291304 .

Hauptmann H. 1993. Ein Kultgebäude in Nevali Çori. In M. Frangipane, H. Hauptmann, M. Liverani, P. Matthiae and M. Mellink (eds.), Between the Rivers and the Mountains, Archaeologica Anatolica et Mesopotamica Alba Palmieri Dedicata. Dipartimento di Scienze Storiche Archeaologiche e Antropologiche dell'Antichità Università di Roma "La Sepienza". Roma: 37-69.

1999. The Urfa Region. In M. Özdoğan, N. Başgelen (eds.), Neolithic in Turkey, The Cradle of Civilization, New Discoveries. Archaeology and Art Publications. Istanbul: 65-86.

2000. Ein frühneolithisches Kultbild aus Kommagene. In J. Wagner (ed.), Gottkönige am Euphrat: Neue Ausgrabungen und Forschungen in Kommagene. Verlag Philipp von Zabern. Darmstadt/Mainz: 5-9.
2012. Ein frühneolithisches Kultbild aus Kommagene. In J. Wagner (ed.), Gottkönige am Euphrat: Neue Ausgrabungen und Forschungen in Kommagene. Verlag Philipp von Zabern. Darmstadt/Mainz:13-22.

Karul N. 2011. Gusir Höyük. In M. Özdoğan, N. Başgelen and P. Kuniholm (eds.), The Neolithic in Turkey, New Excavation and New Research, The Tigris Basin. Archaeology and Art Publications. Istanbul: 1-17.

Mryake Y. 2011. Diclenin İlk Köyü. Arkeo Atlas 8: 4047.

Özkaya V., Coşkun A. 2011. Körtik Tepe. In M. Özdoğan, N. Başgelen and P. Kuniholm (eds.), The Neolithic in Turkey, New Excavation and New Research, The Tigris Basin. Archaeology and Art Publications. Istanbul: 89-127.

Rosenberg M. 2011. Hallan Çemi. In M. Özdoğan, N. Başgelen and P. Kuniholm (eds.), The Neolithic in Turkey, New Excavation and New Research, The Tigris Basin. Archaeology and Art Publications. Istanbul: 61-78.

Schmıdt K. 2001. Göbekli Tepe, Southeastern Turkey. A preliminary report on the 1995-1999 excavations. Paléorient 26(1): 45-54.

2002. The 2002 Excavations at Göbekli Tepe (Southeastern Turkey) - Imressions from an Enigmatic Site. Neo-Lithics 2(02): 8-13.

2007. Göbekli Tepe. In M. Özdoğan, N. Başgelen (eds.), Anadolu'da Uygarlı̆̆n Doğuşu ve Avrupa'ya Yaynlmi, Türkiye'de Neolitik Dönem, Yeni Kazlar, Yeni Bulgular. Arkeoloji ve Sanat Yayınları. Istanbul: 115129.

2010. Göbekli Tepe, The Stone Age Sanctuaries. New results of ongoing excavations with a special focus on sculptures and high reliefs. Documenta Praehistorica 37: 239-256. 


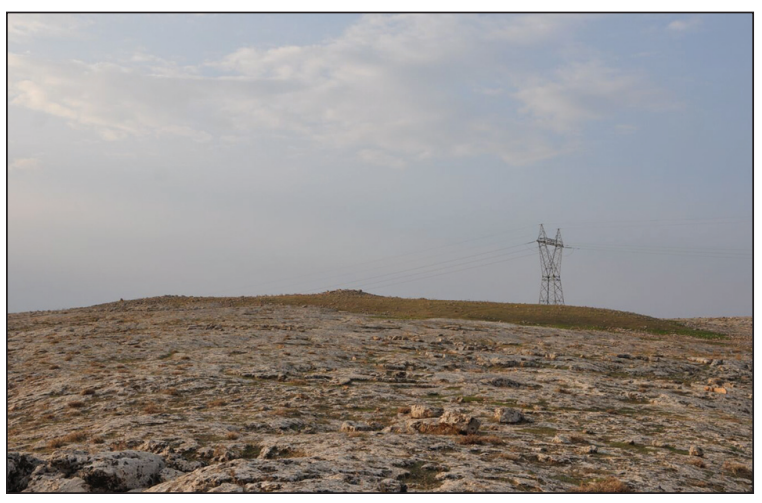

Fig. 1. View of Kurt Tepesi settlement from the south.

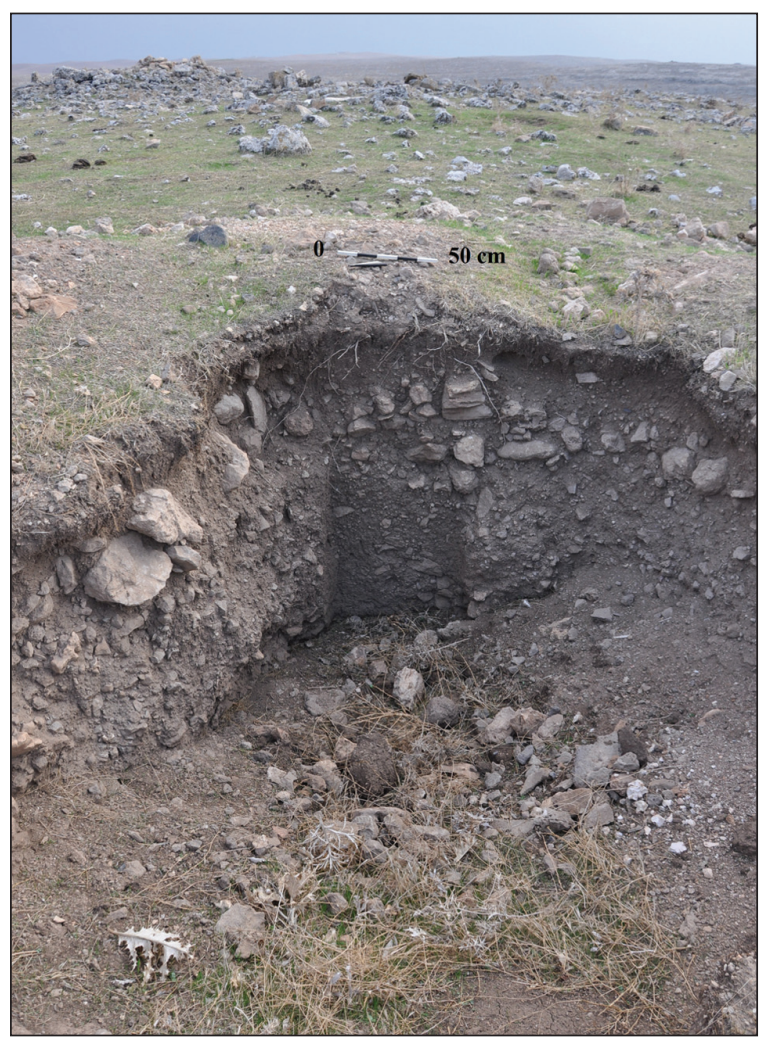

Fig. 3. The site where T-shaped pillars were unearthed due to illegal excavations at Kurt Tepesi.

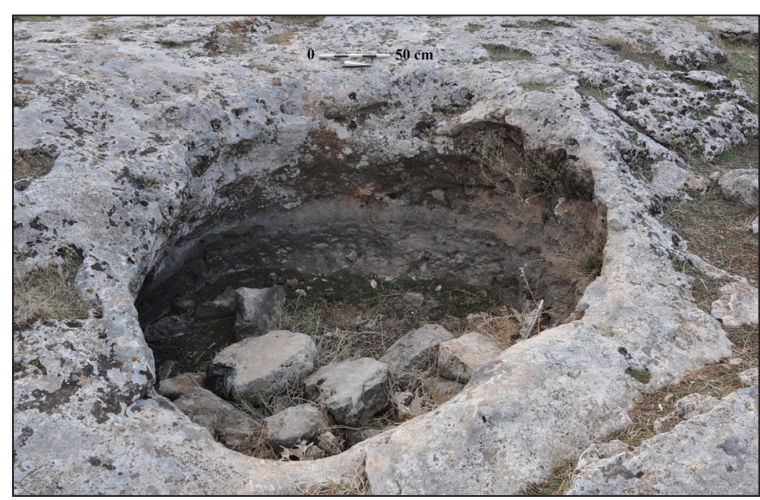

Fig. 2. A pool chiseled to the bed rock at Kurt Tepesi.

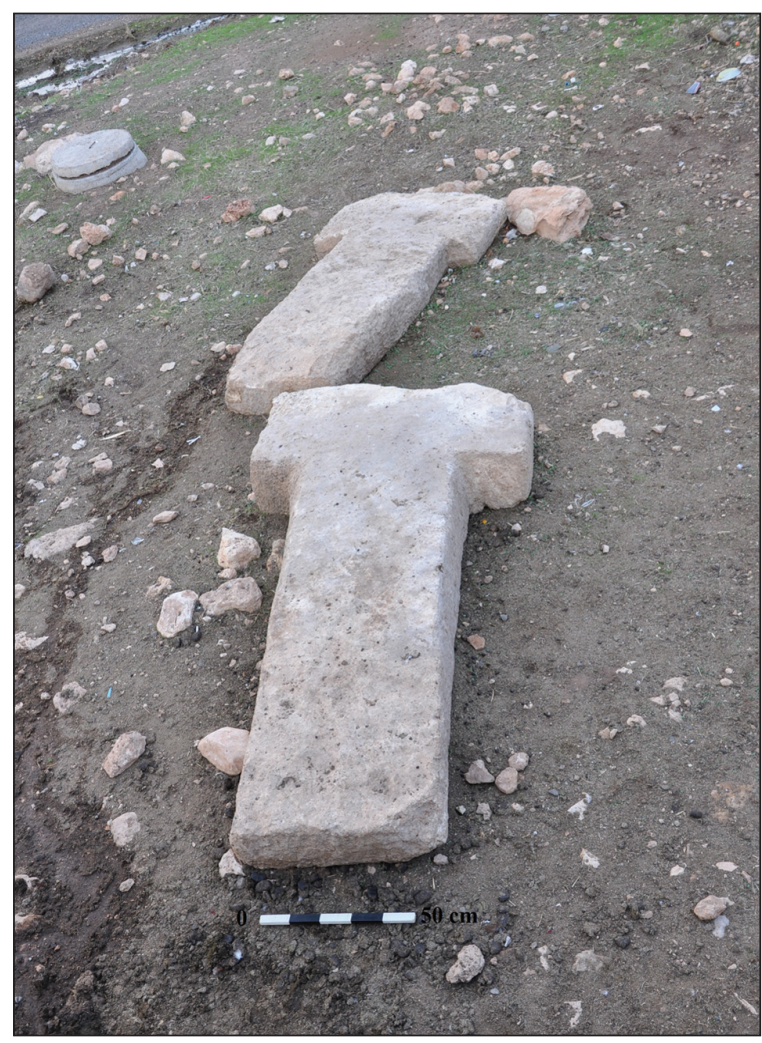

Fig. 4. T-shaped pillars excavated from Kurt Tepesi.

Fig.5. Selamet village Guhera Abid Mevkii triangle shaped snare areas.

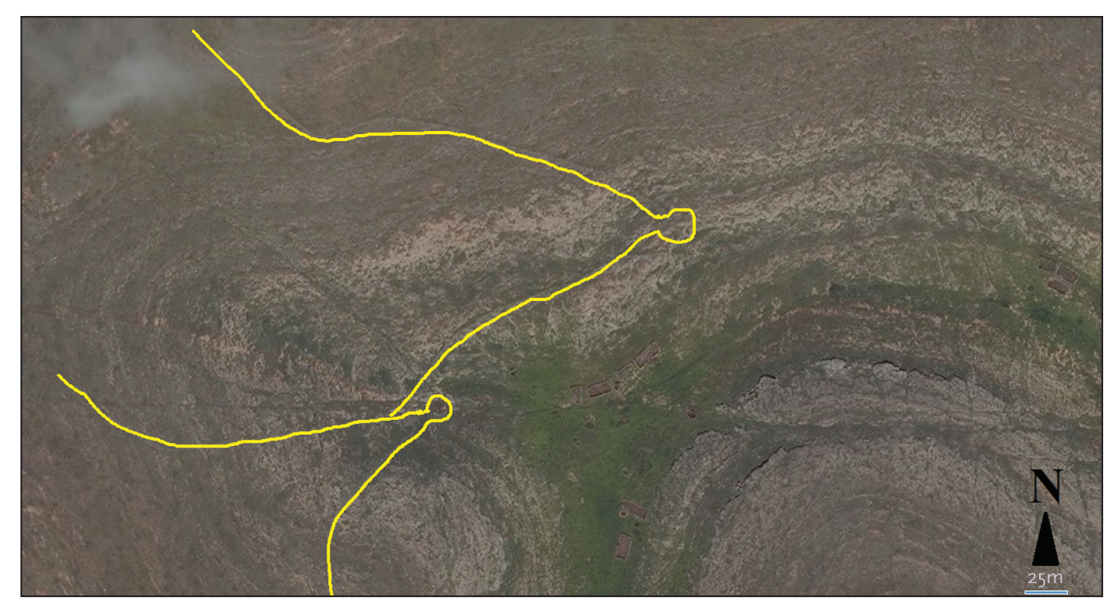




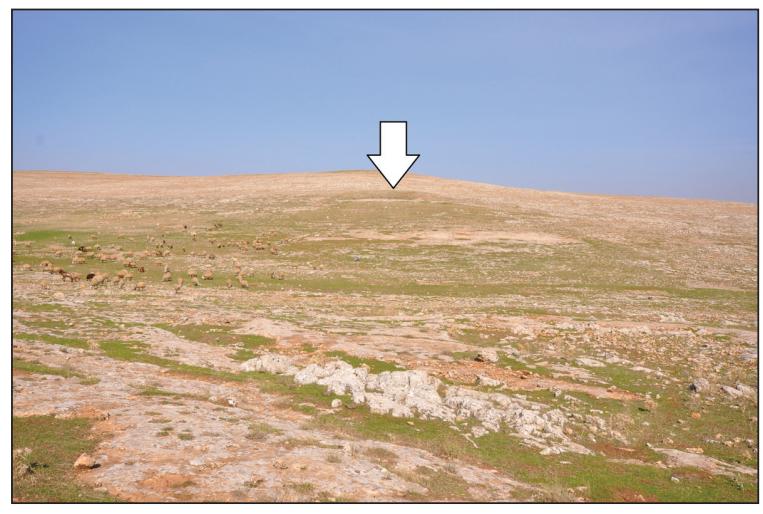

Fig. 6. View of Selamet village Kuzey Mevkii settlement from south.

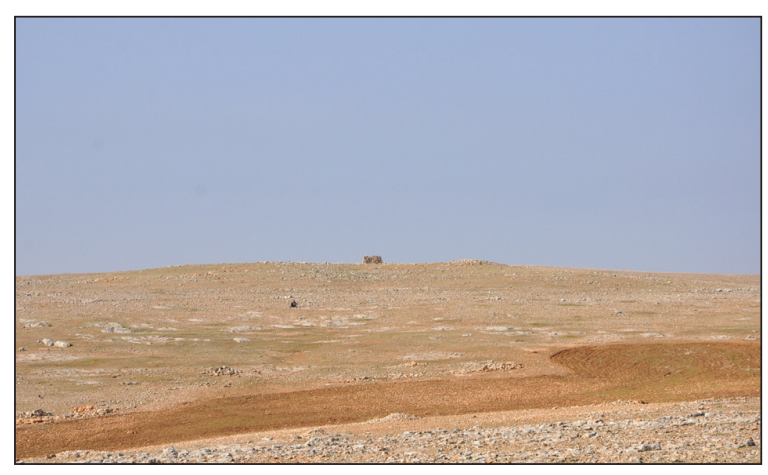

Fig. 8. View of Kuşharabesi village Camçak Tepe from the north.

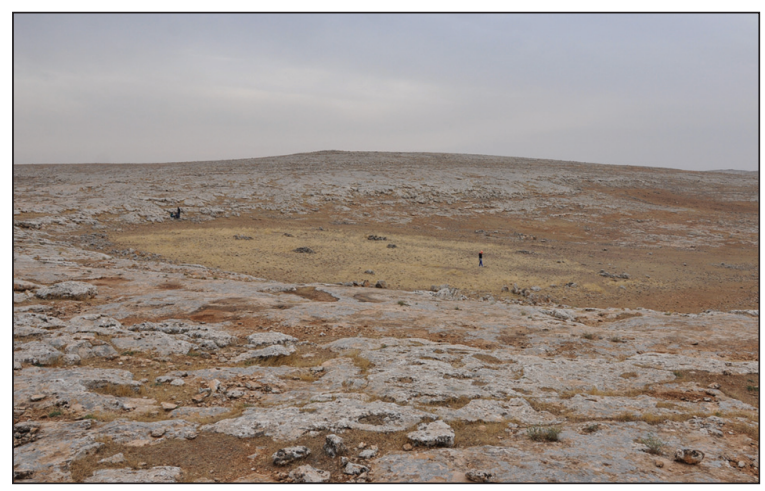

Fig. 10. View of Aşă̆ı Yazıcı Güney Mevkii from the north.

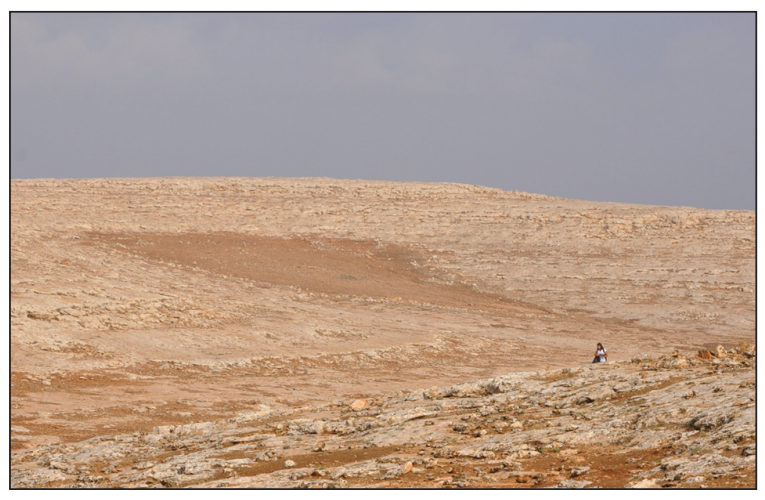

Fig. 12. View of Minzulit Isa from the southwest.

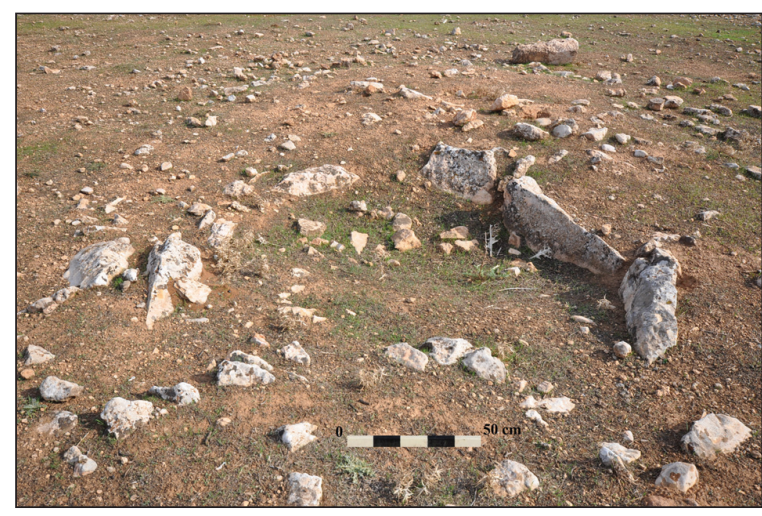

Fig. 7. Remains of a circular building at Selamet village, northern mound.

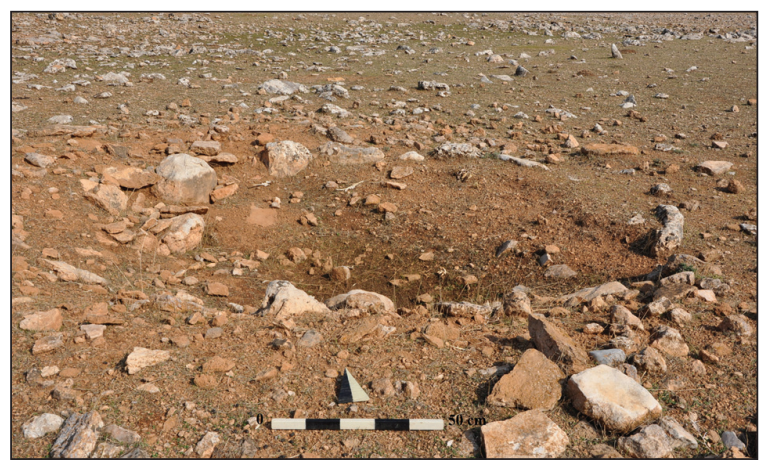

Fig. 9. Remains of a circular building at Camçak Tepe.

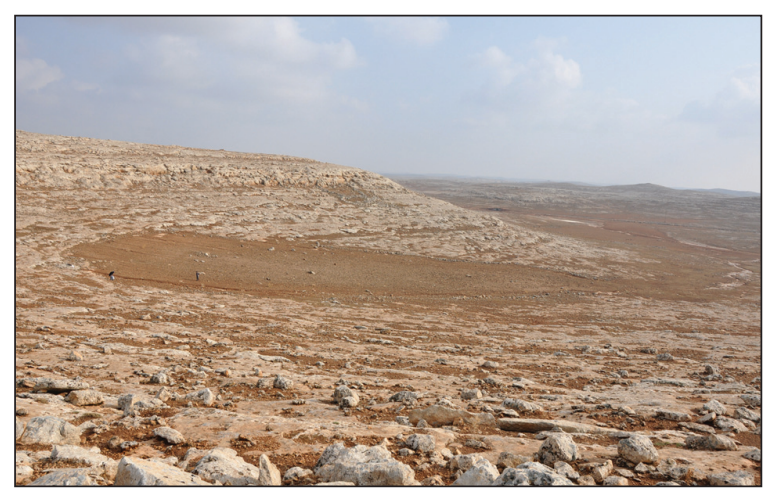

Fig. 11. View of Monzulit Holeyil from the west.

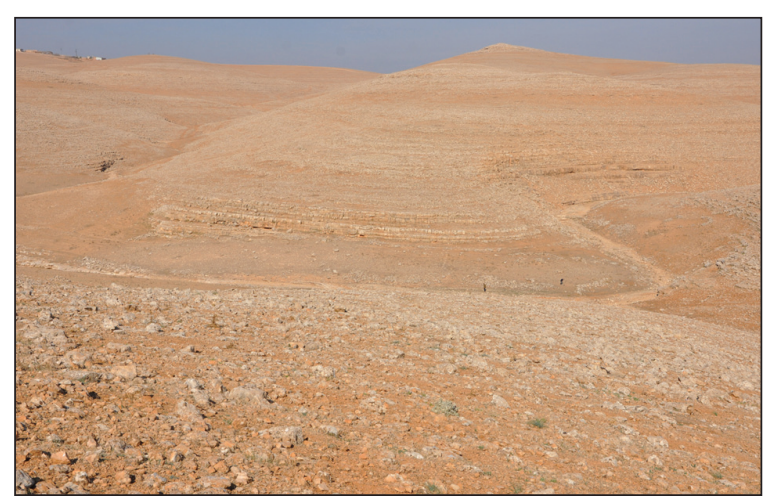

Fig. 13. View of Karakuş village Batı Mevkii from the south. 


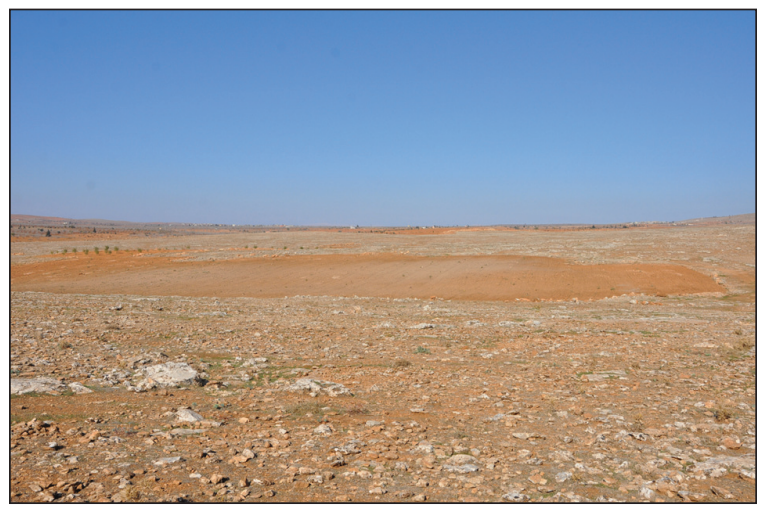

Fig. 14. View of Curaln village Cillo Mevkii 1 from the south.

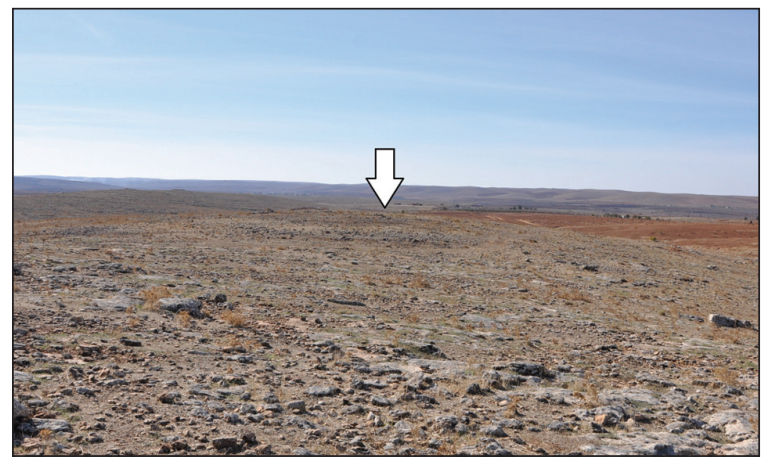

Fig. 16. View of Domuzcurnu Tepesi from the north.

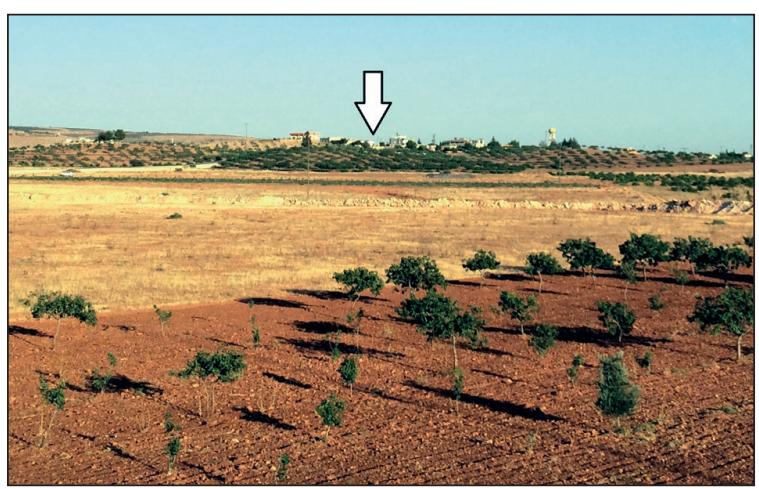

Fig. 18. General view of Ayanlar Höyük from the north.

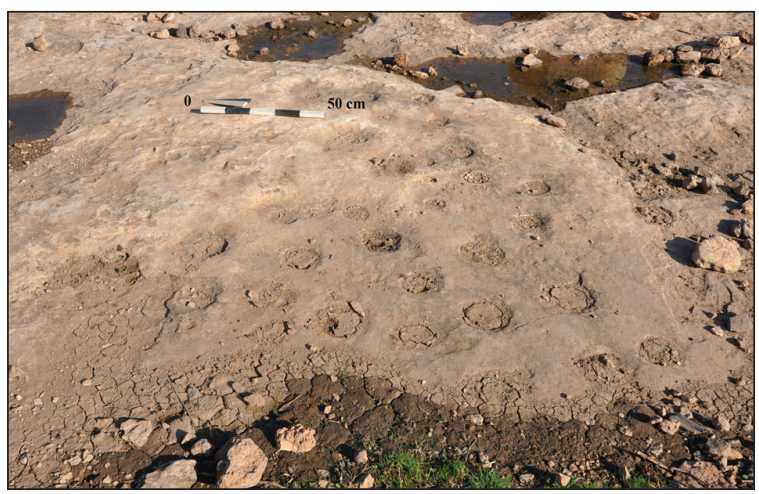

Fig. 20. Cut-put groups from Ayanlar Höyük, which are used for pool construction technique.

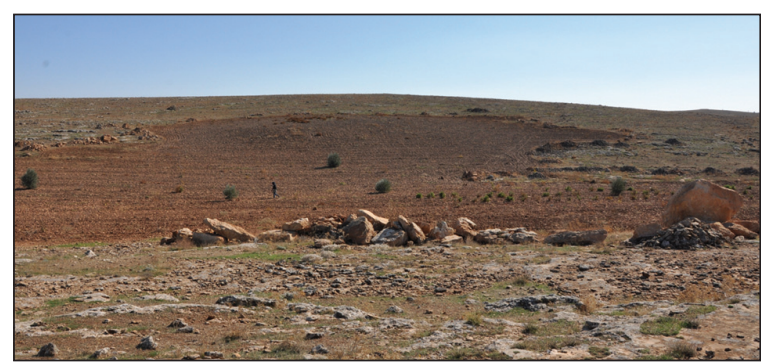

Fig. 15. View of Curaln village Cillo Mevkii 2 from the north.

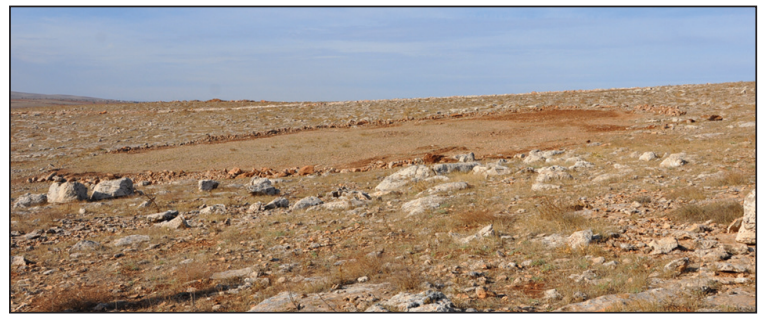

Fig. 17. View of Hasan Sirtı from the south.

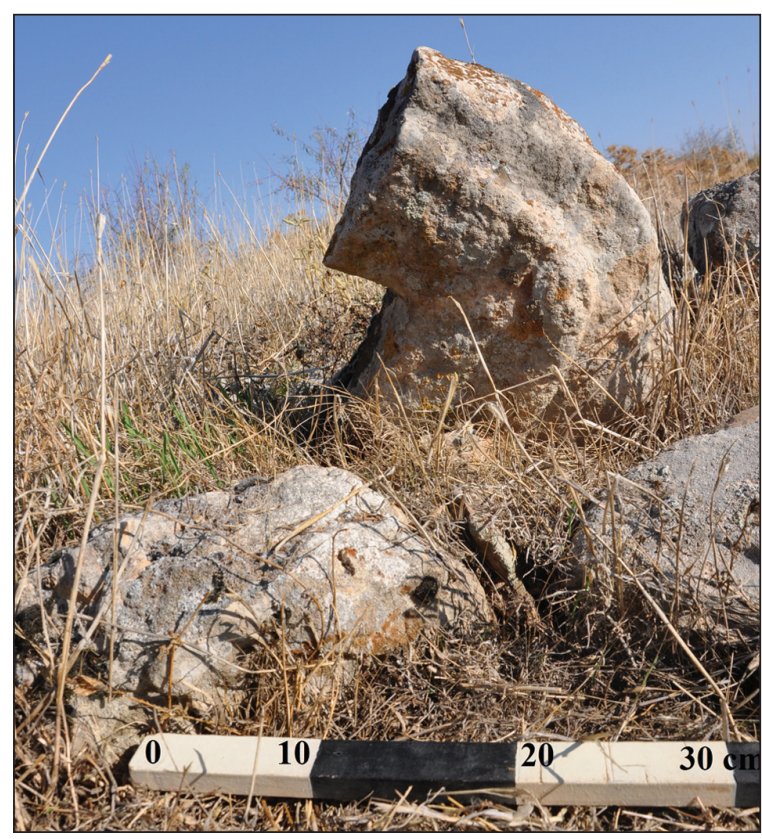

Fig. 19. Pillar pedestal piece with hollow center discovered from Ayanlar Höyük.

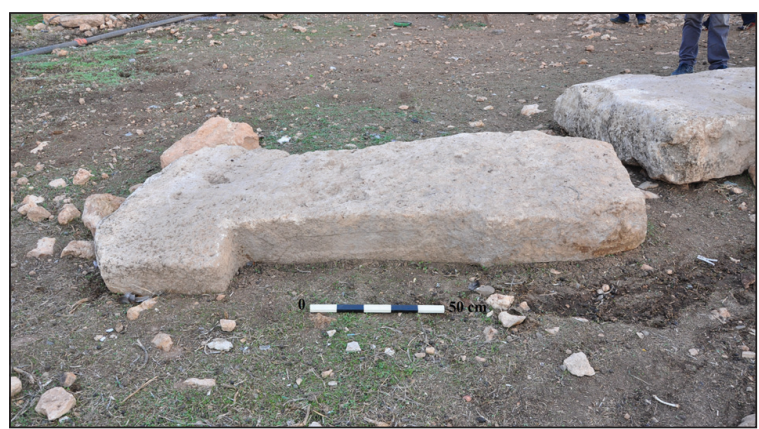

Fig. 21. Pillar with chevron pattern and necktie shaped groove from Kurt Tepesi. 